\title{
The contradictory unity of faith and reason in Christian theoretical thought
}

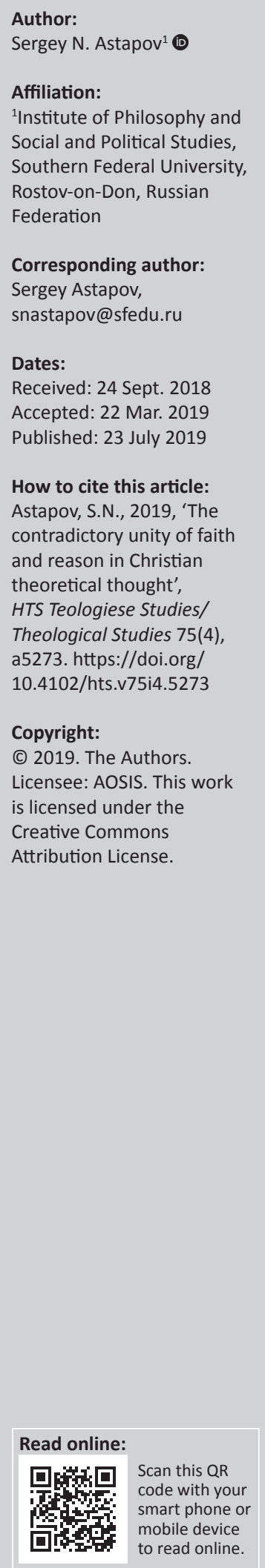

This article aims to demonstrate the unity of faith and reason as irrational and rational elements of the theoretical religious discourse on instances of Christian theoretical thought. This unity was represented as a dialectical contradiction, the violation of which led to the destruction of religious discourse. The contradictory unity of faith and reason was researched in European medieval philosophy and Russian religious philosophy in the first half of the 20th century and in the theoretical systems that were considered ways of explaining the relationship between faith and reason in Christian thought. This article reveals two historical types of the dynamic unity of faith and reason as well as violations of this unity: when medieval authors attempted to find the most effective relationship between faith and reason for Christian theology; and when Russian philosophers attempted to transmit theological knowledge by means of philosophy in the secular age. The results of the dynamic unity violations in both traditions are investigated as the conceptions that had been denied by these traditions. The main conclusion of the article is that Christian theoretical thought maintained the contradictions between faith and reason as a search for its development.

Keywords: Faith; European medieval philosophy; Reason; Religious discourse; Russian religious philosophy; Theology.

\section{Introduction}

Discussions about the relationship between religious faith and the rational content of religious beliefs thread throughout the history of Christian thought and do not lose relevance in the contemporary philosophy of religion. Do religious beliefs have their foundations only in the existence of religious experience or do they have a rational basis too? How important is the rational basis for religious consciousness? These questions are important for theoretical Christian thought, for both theology and philosophy. Alvin Plantinga (2000) expressed this importance in this way:

\footnotetext{
Classical Christian belief includes, in the first place, the belief that there is such a person as God. God is a person: that is, a being with intellect and will ... This is the theistic component of Christian belief. However, there is also the uniquely Christian component: that we human beings are somehow mired in rebellion and sin, that we consequently require deliverance and salvation, and that God has arranged for that deliverance through the sacrificial suffering, death, and resurrection of Jesus Christ, who was both a man as well as the second member of Trinity, the uniquely divine son of God ... Accordingly, our question is this: is belief of this sort intellectually acceptable? In particular, is it intellectually acceptable for us, now? For educated and intelligent people living in the twenty-first century, with all that has happened over the last four or five hundred years? (pp. VII-VIII)
}

In the history of Christian thought, the relationship between religious faith and rational grounds for religious beliefs is denoted by opposition of faith and reason. This article aims to demonstrate unity of faith and reason as irrational and rational elements of theoretical religious discourse on instances of Christian theoretical thought.

The aim seems to bring nothing new. Many authors have written about the unity of faith and reason in religion. However, this article represents this unity as a dialectical contradiction, the violation of which leads to the destruction of religious discourse. Investigation of examples from the history of Christian thought (both preservation of the contradictory unity and violation of it) will be more effective for achievement of this aim than consideration of contemporary authors' arguments for the rationality or irrationality of religious beliefs.

Rational and irrational elements construct a contradiction in theology (which is a sort of religious discourse) because they logically deny each other, but they coexist in dynamic unity, which is expressed by philosophical thought in a form of antinomy. If this dynamic unity is broken, theological discourse is transformed into mystical discourse (in the case when irrational elements 
dominate) or into the discourse of religious philosophy (when rational elements dominate). The term 'religious philosophy' is used in this article to signify the kind of philosophy that has religious character, which is a sort of theoretical religious discourse. The Anglo-American philosophical tradition uses the term 'philosophy of religion' for this philosophy. ${ }^{1}$ However, the first term emphasises the thought that it is philosophy in religion more than philosophy about religion.

The contradictory unity of faith and reason will be demonstrated by the examples of two historical types of religious philosophical discourse: European medieval philosophy and Russian religious philosophy from the first half of the 20th century. These discourses are interesting for the topic of the article because they demonstrate two models for explaining relations between faith and reason in Christian thought. The first model is subjugation of philosophical discourse for purposes of the religion of revelation. It demonstrates what kind of relation between faith and reason is the most effective for Christian theology. The second model represents transmission of theological knowledge by means of philosophy in the secular age, when rationality and science dominated consciousness and among theories. Moreover, the case of Russian religious philosophy is interesting for the topic because Russian philosophers were criticised by theologians of the Russian Orthodox Church for exceeding Christian doctrine and pantheism.

In this article, neither Protestant theology and philosophy nor Catholic philosophy of the 20th century is specially considered. At first sight, it results in discrepancy with contents of the article. However, the aspiration to review all theological and philosophical systems of Christianity would lead to the fact that the article either would turn into a set of descriptions or expand to a monograph volume. In that case, it would be required to include both theology of the Armenian Church, Coptic theology, and theology of the Assyrian Church of the East. It is represented that the most important element is to show the most striking examples from Christian thought, and what is more, not to separate but to unite certain spiritual traditions in which this contradictory unity was realised.

Protestantism is extremely varied in this regard. Protestant theology is represented by different points of views on the considered issue such as Luther's, Schleiermacher's, Harnack's and Bart's views. The contemporary Ukrainian researcher of Protestant theology, M. Cherenkov, noted that:

Protestant theology accenting the principles 'Quinque Sola', supplementing each other, became in some sense fundamentalist: it was constructed on the bases of Bible's faith without history, i.e., without theology and philosophy in their historical forms. But this fundamentalism in its adherence to the Scripture and Christ delivered everyone from any other authority for the

\footnotetext{
1.The appellation 'Anglo-American philosophical tradition' is used here, followin R. Suinburne (Swinburne 2007:89), for Anglo-American analytic philosophy of religion. According to definitions of its problem field made by Suinburne and several religion. According to definitions of its problem field made by Suinburne and several
of its famous representatives (Alston 1998:238; Plantinga 1984:268; Pojman \& Rea of its famous representatives (Alston 1998:238; Plantinga 1984:268; Pojman
2008:XV-XVI; Taliaferro 1998:4-5), it has a character of religious philosophy.
}

personal and creative relation. It is similar as in non-Euclidean geometry through the point, which is not lying on a straight line, can be drawn many parallel to the straight, - in Protestant theology the prospect of creation of a set of the philosophies developing initial theological premises was revealed. It answers the question why the Protestant theology proceeds in the most various and conflicting philosophical and religious approaches instead of creating unique philosophy of religion. (Cherenkov 2011)

The 20th century gave the whole range of Protestant theologies different collisions between faith and reason and even different understandings of belief. Protestant philosophy is, in this sense, even more varied. One pole of it is Kant's philosophy, and the opposite pole is Kierkegaard's philosophy. Therefore, Protestant thought in this article is presented as appeals to representatives of modern philosophy of religion, such as A. Plantinga.

\section{Three discourses on Christian theoretical thought}

Religious discourse, considered either in communicative situations, immediately, or as a text belonging to a certain author, time, religious tradition, national culture and so on, contains rational and irrational components.

The complexity of these components is represented as syncretic unity of heterogeneous elements on the level of everyday communications and a specific contradiction on the theoretical level of religious consciousness. A discourse is understood in this article as a speech in its social context where the context determines the main features of the speech. The religious context requires not only informing about something but also rousing to activity concerning a subject of religious belief. In other words, religious discourse is a set of propositions transmitted by any religious author that have the purpose not only of giving information but also expressing its importance for an individual or a social group in his or its relation to a supernatural being and its own being, which is understood as depending on the supernatural one.

This article does not state that the religious consciousness of an individual is tortured by the contradiction between reason and faith. Reason and faith can complete one another. An individual can accept some statement by faith, and then he or she can find an affirmation of the statement through his or her experience or reflection. Moreover, the everyday religious consciousness is syncretic and eclectic, which means that, depending on circumstances, either faith or reason becomes dominant. However, can religious philosophy discourse and religious mysticism discourse sit alongside one another as two sorts of theological discourse? Is there a clear border between the discourses of religious philosophy and theology? Might the discourse of religious philosophy be called 'discourse of reason' and the discourse of theology called 'discourse of faith'?

Indeed, religious philosophy discourse and religious mysticism discourse sit alongside one another, but the two sit 
alongside theological discourse. The border between religious philosophy and theology can be invisible for Western Christianity, which produced such disciplines as 'philosophical theology' and 'non-confessional theology'. However, it is clearly visible for Eastern Christianity. ${ }^{2}$ Philosophy has the intention of explaining all existence through rational deductions, of finding rational arguments for the propositions that express religious experience. It is a 'discourse of reason' in the strict sense. Theology knows the incomprehensible mystery of God. From the point of view of theology of reason, when it meets aspects of this mystery, it must reverentially stop its activity and fall silent in its explanations in order not to turn away from the Divine Truth.

Mystical discourse, which is discourse of religious poetry, symbols and metaphors, is not a theological discourse because mystical discourse is independent of a number of religious tradition norms and does not convey traditional points of views on relations with the supernatural. Speculative mysticism (of J. Eckhart, J. Böhme, etc.) could be considered a kind of philosophy because it solves the philosophical task, which is explanation of mystical experience by rational means, and this solution is achieved through the use of known philosophical concepts, approaches and theories. However, speculative mysticism should be distinguished from philosophy in two ways. Firstly, criticism that is peculiar to philosophy does not belong to it. Speculative mysticism using achievements of philosophy eclectically combines elements of different philosophical theories. It compiles different arguments that are received sometimes opposite from another theoretical approach. Secondly, it does not solve the task of strengthening an individual in faith, which is the task included in a set of theological tasks.

Neither mystical discourse nor philosophical discourse expresses completeness of religious thought: mystics is subjective and does not transmit experience of religious tradition, while philosophy is critical and does not transmit experience of a meeting with the supernatural being. That difference is why Christian theologians perceive them (philosophical and mystic discourses) as two divergent ways of religious thought (the heresies).

Mystical and religious philosophical discourses are in proximity to theological discourse, but are not equal to it. It should be distinguished from the discourse of theology and from the discourse of mystics and the discourse of religious philosophy. They are three kinds of religious discourse. Mystical discourse differs from two other discourses by its picturesque and metaphorical style and its non-logicality. Moreover, in some forms, it is characterised by spontaneity of speech. Religious philosophy proceeds from these premises, which are accepted by reason exclusively. Theology, in addition, accepts premises 'from revelation' that are maintained by sacred scriptures and doctrinal formulas of the specific religious tradition.

2.An example of distinction between theology and religious philosophy is given by the . Ar exa distinguis prict distinguished religious philosophy from theology as a free reflection on the mystery of God and creation, which may go beyond the limits of Divine revelation' (Van Rossum 2012).

\section{Specific features of religious faith}

The rational sphere of consciousness can be described by the following essential characteristics: the logical form, systematism, criticism, argumentation and transmission of concepts, expression of essential properties and qualities of cognised objects. The out-logical form of expression, spontaneity, dynamism, integrity and value accentuation are the characteristics of the irrational sphere of consciousness. The irrational sphere is formed by faith, experiences and sensory data, that is, by pre-rational psychics. However, it is not true to say that religious concepts do not have irrational elements. Despite the fact that conceptualisation implies rationalisation, the irrational elements continue its existence in concepts in other forms. Therefore, rational components in religious concepts are explained by appellation to experiences of a meeting with a supernatural being, that is, by irrational experiences of some individuals or religious tradition. Then, theologians and religious philosophers state that the irrational sphere is a basic cognitive ability like intuition (Florensky 1990:25-43; Frank 2000:306-352; Trubetskoy 1998:264-265). Finally, religious consciousness expresses its content in images and symbols. Therefore, conceptualisation does not set free religious consciousness from the sensuous sphere and irrational elements concerned with it.

Faith is the main element of the irrational sphere of consciousness and the basis of religious beliefs. Psychologists consider faith the specific state of psychics related to anticipation of something wished (Bratus \& Inina 2011:26). This state arises in situations of vagueness or probability and, moreover, in relation to the events or the ideas that have importance for an individual or a social group. When an event has occurred or is evidently impossible or when a proposition has been verified, faith dies down or it transforms into proved knowledge. Likewise, if an event or an idea is not important for an individual (or a group), it will not be the subject of faith.

Religious faith has six specific features (at a minimum) that distinguish it from other sorts of faith:

1. It is a faith in the reality of a supernatural being.

2. It is a faith dependent on processes and events in human life and in the world from activity of the supernatural being.

3. It is a faith in manifestations of the supernatural being in the environment. According to religious consciousness, the supernatural is found in a miracle, that is, in an act of radical intervention of the supernatural in the order of nature, an act of interruption of natural and social laws.

4. It is a faith in communication with the supernatural and in the possibility of influencing the supernatural as a result of this communication.

5. It is a faith in the truth of the ideas, the doctrines and the theories of the supernatural.

6. It is a faith in the authority of some individuals (the prophets, the saints, the ministers of religious worship, etc.), who communicate with the supernatural. 
It follows from this set of religious faith features that a deist's faith cannot be considered religious faith. A deist's faith does not suppose a connection between an individual and God, and does not place the life of an individual as dependent on God. Therefore, this faith is indifferent to forming human behaviour, relations to people and the world, or the way and meaning of human existence. This faith is a philosophical faith.

According to Stephen T. Davis (2009), faith in divine revelation is the feature distinguishing Christian beliefs from deism:

The Deists importantly differed from traditional Christian thought in their rejection of all robust notions of divine revelation (except 'natural revelation', i.e., conclusions about God and religion reached by unaided human reason). Indeed, they rejected all claims of divine intervention in the world - not only special revelation but also miracles, epiphanies, and incarnations. (p. 30)

Religious faith is different from the faith that exists in the everyday life of an individual by absence of its orientation to the most probable. Russian religious philosopher S. Frank wrote that religious belief was a belief in a transcendent subject. The belief cannot be tested by any direct empirical experience or a scientific experiment. There is no less probable issue for rational thought than 'the hypothesis of existence of God' (Frank 2007:13). Religious belief or faith, according to the words of Frank and other Christian authors, exists only as a consequence of a single circumstance: it is based on revealing God himself, that is, direct communication with the supernatural as the source of it.

Of course, not only immediate experience allows us to claim the existence of God. An individual can accept some beliefs in God through a preacher's speech or by reading the religious literature when the influence is through events of personal, non-religious experience or by influence of religious tradition in which an individual was raised. However, in all these cases, an individual will verify his beliefs, and will collate them with something else. Only the experience of meeting the supernatural (e.g. a miracle) will become a solid basis of religious beliefs.

\section{The problem of correlations between faith and reason for European medieval thought}

The majority of medieval Christian authors put priority on faith against reason. This priority is explained by Christianity being a religion of salvation. The Christians believe in the salvation mission of Jesus Christ. If this belief is considered from the position of reason, its content seems absurd. To sacrifice the goods of the current life for a promise and to attest blessedness after death seem insanity. However, Jesus Christ calls it exactly: 'Sell that ye have, and give alms; provide yourselves bags which wax not old, a treasure in the heavens that faileth not, where no thief approacheth, neither moth corrupteth' (Lk 12:33). At the same time, according to the Christian doctrine, it is not necessary to be a sage to make himself ready for the eternal life:

Where is the wise? where is the scribe? where is the disputer of this world? hath not God made foolish the wisdom of this world? For after that in the wisdom of God the world by wisdom knew not God, it pleased God by the foolishness of preaching to save them that believe. (1 Cor 1:20-21)

The line of the opposition of faith to reason was expressed clearly by apologists Tatian the Syrian and Tertullian. They stated all considerations of the world or God were vain and vainglorious. However, they used reasons for justification of Christian belief. Tatian addressed Greek philosophers:

Cease to make a parade of sayings which you have derived from others, and to deck yourselves like the daw in borrowed plumes. If each state were to take away its contribution to your speech, your fallacies would lose their power. While inquiring what God is, you are ignorant of what is in yourselves; and, while staring all agape at the sky, you stumble into pitfalls. The reading of your books is like walking through a labyrinth, and their readers resemble the cask of the Danaids. (Tatian:XXVI)

Tertullian fought against ancient philosophy with its own logical weapons - paradoxes. One of Tertullian's paradoxes found its expression in the sentence (which arose later, after Tertullian), 'Credo, quia absurdum est'. It has a basis in the passage of Tertullian's work On the Flesh of Christ:

The Son of God was crucified; I am not ashamed because men must need be ashamed of it. And the Son of God died; it is by all means to be believed, because it is absurd. And He was buried, and rose again; the fact is certain, because it is impossible. (Tertullian:5 [4])

This line declaring the absolute authority of faith and the negative relation to reason passes through all Christian thought, and it is illuminated by the flares of antiintellectualism in the works of Peter Damian, Bernard of Clairvaux, Søren Kierkegaard and Lev Shestov.

Arnobius the Elder, an apologist, later compared with Tertullian, did not deny the importance of logical arguments for justification of Christian religion. He, using these arguments, demonstrates that faith in Jesus Christ is more pragmatic than faith in any ethnic gods or philosophical doctrines. He states that considerations of ancient philosophers are presuppositions requiring faith. However, it is better to have faith in Jesus Christ than in presuppositions of philosophers. In the first case, it will be a faith in one's own salvation, and in the second case, it will be a faith in various individual opinions (Arnobius:II, 4-11).

St Augustine Aurelius, like Arnobius, saw the importance of reason as a means for validating Christian faith. According to Augustine, an individual, directed by reason, chooses the true subject of religion.

Hereby, Augustine constructs the main statement of Christian knowledge: faith gives truths on religious subjects to an 
individual, but reason inclines the individual to them. Therefore, faith and reason determine each other. In the book On Order, Augustine defines faith as adoption of a thought with consent. It has advantage over reason because it is available to each individual. At the same time, the ability to reason is developed differently in different individuals, and wisdom is a property of the few. ${ }^{3}$ Moreover, faith in Jesus Christ gives salvation to everybody. At the same time, reason does not have the property of salvation. Faith has priority in time, but reason has priority in the essence of a fact because faith is only the first step of cognition. The final purpose of cognition is contemplation of God. ${ }^{4}$

This reflection was called, by Augustine, a light of the Truth, illuminating a mind. Augustine wrote that there is God as the source of intellectual light, and an individual discerns ideas and concepts with the help of this light, like his eyes discern things with the help of an outward light. ${ }^{5}$ Thus, the process of cognition, according to Augustine, leads to God as the Truth. The process consists of three stages. In the first stage, an individual looks for and recognises traces of God in the world. He or she goes from a phenomenon to its cause and then to the cause of this cause, and so on. Thus, he or she approaches the knowledge of the First Cause. ${ }^{6}$

In the second stage, an individual looks inside him- or herself, and he or she appeals to the soul, and he or she knows God through his image in the soul, called the 'interior man' by Augustine. Three superior abilities of a human being are evidence of God: memory, thinking and will. In the third stage, an individual understands inconstancy and imperfection of the spirit. He or she rises over him- or herself and contemplates the constant and eternal Truth. ${ }^{7}$

According to the Christian doctrine, God is the Truth, the truth that does not depend on human knowledge, which is the external authority to humans and their knowledge. This authority can be accepted only by faith. Therefore, the way of faith is the direct way to the Truth. However, the Truth can be opened immediately for a few individuals. The overwhelming majority of people accept it through authoritative evidence of those few individuals. Reason can turn out to be both a helper and a barrier for comprehension of the Truth. Reason can convince others to accept other external authorities because the authority of the Truth is not a single external authority. However, Christianity teaches humans the image and likeness of God. Therefore, reason by humans is the image and likeness of the Divine Logos, and any imprint or reflection of the Truth must be in reason.

The balanced contradiction of faith and reason can be seen in the works of Eriugena, Anselm and Duns Scotus (the author

3.De ordine libri duo: 11,5 [16], 9 [26]. Titles of Augustine's work in Latin refer to the electronic bibliotheca 'S.Aurelii Augustini opera ominia - editio Latina' (Augustine).

4.De vera religione liber unus: 24 [45].

5.De Genesi ad litteram libri duodecim: XII, 31 [59].

6.De Trinitate libri quindecim: XII, 15

7.De civitate Dei contra paganos libri XXII: XI, 28. who tried to put reason over faith, but does it very carefully, with many reservations), and the breaking of the balance can be seen in Peter Abelard's philosophy as well. Abelard states the priority of reason. If the Son of God is named Logos, logic must be sacred. Moreover, history presents human knowledge as based on increasing reason but not increasing in faith, and always there is the danger of false faith. ${ }^{8}$ Faith is defined by Abelard as a presupposition of the things that are invisible and inaccessible to the senses, that is, a presupposition of unauthentic and doubtful things. ${ }^{9}$ In that way, Abelard shifts faith from the sphere of the super-rational truth that was described by Augustine and Anselm to the sphere of probability.

Abelard's position destroys the basis of religious consciousness because it instigates rational investigation of doctrinal statements of religion to conclude the possibility of believing in these statements. Christian theology negatively estimates a desire to test all beings by reason because the individual, claiming exclusive right to reason to cognise all beings, states his own absoluteness.

A vivid example that absolutism of reason brings denial of religion was demonstrated by the French Enlightenment. Philosophers of the Enlightenment started with the declaration determining the role of knowledge, especially the knowledge of 'natural laws', for correction of social relations, and then they proclaimed that the Christian Church was a stronghold of ignorance and obscurantism. They considered God to be the wise First Cause, the architect who planned and created the world, but who did not interfere with its processes. Some of these philosophers (Diderot, Helvetius, Holbach and La Mettrie) took up an atheistic position. ${ }^{10}$

According to Christian theology, the absoluteness of God does not permit cognising his essence, whereas rational cognition aims to comprehend the essence. God is transcendent, and only his properties are comprehensible through analogies of his creatures. If man were able to comprehend God, he would become equal to God. However, a creature cannot be equal to its creator. The essence of God cannot be expressed by concepts because the meaning of the word 'concept' (according to its Latin etymology) is 'grasp' or 'acceptance'. That meaning is why there is tradition (especially, in Easter Christianity theology) of distinguishing rational (positive, cataphatic) knowledge of God from mystical (negative, apophatic) knowledge. Cataphatic theology and apophatic theology are not two ways of knowledge of God independent of each other. According to Dionysius the Areopagite, the cataphatic way is preliminary 8.Petri Abaelardi introductio ad theologiam in libris tres divisa: II, 1051. References to Abelalard's works in Latin are given according to Migne's 'Patrologiae cursus completus. Series Latina' in electronic bibliotheca [Migne].

9.Petri Abaelardi invectiva in quedam ignarum dialectices, qui tamen ejus studium reprehendebat, et omnia ejus dogmata putabat sophismata et deceptions: 355 .

10.Despite the fact that La Mettrie criticized Diderot's deism in 'Philosophical Thoughts', Diderot in 'The Skeptic's Walk', as I. Jonathan considers, moved away from deism towards materialism and atheism (Jonathan 2006:791, 818). On from deism towards materialism and atheism (Jonathan 2006:791, 818). On
atheism of Enlightenment, see also Newland (1974), Smith (1965) and Vartanian (1960). 
to the apophatic one, and theology becomes apophatic when it drains its cataphatic resources.

For Dionysius the Areopagite, the author distinguishing between cataphatic from apophatic theology, God is the total 'Super', the Super-good, the Super-living, the Super-wise, the Super-essential and the Super-Divine Deity. God connects with the world through Divine powers, which are called diakrises [distinctions] by Dionysius. Diakrises must be understood as progressions (outcomings) of God to the outside. God appears himself in diakrises as anything qualitative. His qualities can be called the Good, the Beautiful, the Being, the Life-producing, the Wise and others. God becomes cognisable and expressed in concepts, propositions and deductions (Dionysius the Areopagite 1897:19-21). It means that there is no individual, who comprehends God by the power of his mind, but there is God, who reveals himself to an individual or, more exactly, there is a process in which an individual goes up to God as much as God, through his diakrises, goes down to the individual. Thus, knowledge of God is the act of 'synergism', of cooperation between activities of God and an individual. However, cataphatic definitions testify to the relationship of God with the world and do not testify to God himself. To achieve knowledge of God himself requires 'extracting' him from relations with the world. The 'extraction' can be done by abstraction from the qualities that are related to God in his Divine diakrises, as they are related to subjects of the world. This method is a way of negating the names used to refer to God on the basis of worldly analogies. As a result, God becomes nameless. An individual can say about God only that He is non-being, nobody and nothing. This process is negative theology (Dionysius the Areopagite 1897:83).

The method of 'negative knowledge' of God suggests that an individual must except himself or herself out of the world, that is, it suggests ascetism and prayerful solitude. In that way, the apophatic line becomes the mystic line and develops in hesychasm, a practice of sacred silence in Orthodox monasticism that aims to contemplate the Divine and Uncreated Light. However, the apophatic line was not a parallel line to the cataphatic one. These lines intersected because, on the one hand, the cataphatic way arises from descriptions and explanations of immediate religious experience, and on the other hand, the apophatic way arrives at mystical contemplations and requires description of the process of the contemplations (more exactly, the procedure, 'technique' of it), its results and correlations among them and everyday life.

The situation can be illustrated by the considerations of Gregory Palamas, a Byzantine theorist of Hesychasm, as a mystical and ascetical current in Orthodox monasticism aimed at conjunction between a human and God. According to Palamas, God is inaccessible to intellectual cognition. Therefore, it is not possible to learn anything about the essence of God. True knowledge is not achieved by reason. This knowledge is given by God. A human as the image and likeness of God has immediate experiences of him that are independent of investigation of the world. Ascetics, especially hesychasm, is a practice of ascending to God:

These, who were cleaned by hesychasm, receive the invisible contemplations, but the essence of God remains inaccessible, though who received ones are initiated to His mysteries and reflect on the sighted beings. In that way they having the impassive and asomatous mind unite themselves with the Divine gift of His light, accessible for a mind, at the same time, they know the Divinity is over all contemplations and all contemplative initiations. Thus, they receive the supernatural grace, inaccessible for us, when they know the invisible not through the invisible being (like those, who theologize by deprivation of the properties), but through vision they know the being, which is over vision, and feel deprivation out the reasoning. The accepting and vision of Deity is other and over cataphatic theology. Likewise the accepting of negation which occurs in the spiritual vision is other and over apophatic theology, since the visible is excessive. (Gregory Palamas 2006:213-214)

In other words, Gregory Palamas represented the Orthodox apophatism and stated the principal unknowableness of God, but at the same time, he said God reveals himself to an individual who looks for communication with God in his 'spiritual mind'.

The complexity of Palamas' speech construction is perceptible. It is not only a manifestation of 'the Byzantine style' of a speech, but also an expression of Palamas' desire to transmit the content of mystical experience through reasonings, that is, through reason. Reason, in this situation, comes to contradictions that are expressed in speech by oxymora and metaphors, in discourse by paradoxes and symbols, and in philosophical reflections by antinomies, that is, by the kinds of a speech and thought that are forms of the contradiction of faith and reason.

\section{The problem of relations between faith and reason: the point of view of Russian religious philosophy}

A Russian philosopher in the first half of the 20th century, S.N. Bulgakov (1994), noted that all religious thought presented itself as evolution of the contradiction between the transcendent and the immanent:

The object of religion, God, is something, on the one hand, absolutely transcendent, foreign to nature, outward to the world and to a man, but on the other hand, He reveals to religious consciousness, touches it, comes into it, becomes the immanent content of it. Both moments of religious consciousness are given synchronously, like poles in their pushing off and attraction. (p. 88)

Bulgakov expressed transcendence of God by the Greek A (a-privativum in grammar, i.e., Nobody) and his immanence by Ōn (the Existing). He believes apophatism is a tendency of thought towards A, and cataphatism is the tendency towards On, but both of them are based on faith in the revelation of the supernatural Divine being (Bulgakov 1994:92-93). This faith can be called, figuratively (according to another Russian 
philosopher, P. Florensky), the effect of vision of 'azure of the Eternity through gaping cracks of the human reason' (Florensky 1990:483).

S. Bulgakov wrote that if cataphatic consideration is given by the individual who does not have experience with the mystical revelation of God, then it is not quite clear what kinds of symbols are used by the individual and what is the reason for this use. Apophatism does not have to be 'naked negation', that is, rational or irrational negation of some characteristics of being on behalf of non-being. The negation must be based on substitution of characteristics of our world by characteristics of the hidden (unspeakable), supernatural world.

The other Russian philosopher, Aleksey Losev, asserted the dialectical unity of faith and reason as unity of two points of cognition. Faith fixes a subject of cognition, but a process of cognition concludes in examination of signs or indications of the subject, which is the work of reason (Losev 1991:104-105).

Losev's consideration reproduces the thought of Vladimir Solovyov, a Russian philosopher in the second half of the 19th century. Solovyov (2011) believed that faith was the precondition of knowledge, which provided connection between the outward world and the content of our consciousness. He wrote:

If we did not believe in existence of the outward reality, all that we experience and know would have exclusively a subjective significance, would represent exclusively data of our interior psychical life. (p. 40)

Solovyov pointed out that religious faith was, first of all, a faith specialised through its subject, the Divine being, which is why he concluded: 'Existence of the outward world and existence of the Divine principle both are exclusively probabilities or conditional for reason, they can be stated unconditionally only by faith' (Solovyov 2011:41).

Russian philosophers pointed out the certain unity of faith and reason in cognition expressed through competition between them (as ways of representing knowledge of consciousness) in religious discourse. Dogmatic discourse is the opposite of discourse trough explanations and proofs. Moreover, dogmatic discourse contains the unity of immediate faith and arguments from authority (of religious tradition, leaders, scriptures, etc.). The immediate faith can be considered like mystical intuition, just as S. Frank considered it.

According to Frank, mystical intuition (i.e. faith) apprehends this reality as the non-different totality that can be called the transfinite and transdefinite reality, the Absolute or God. Reason reflects the reality of the world of different subjects with all differences and contrasts among them. It looks at the transfinite and transdefinite reality through analogy with the world. Because differentiation cannot be applied to the nondifferent totality, it cannot be expressed by any concepts. However, cognition of all existing gives a picture of a light of absolute reality through a number of subjects. This picture can be seen by the unity of mystical intuition and rational activity, that is, by the unity of faith and reason (Frank 2000:324-325). ${ }^{11}$

In contrast to S. Frank, S. Bulgakov does not consider religious faith to be a sort of intuition. He distinguishes faith from intuition using three features. Intuition has its roots in everyday experience, but faith has its source in the person's free will and is directed to a transcendental one. Intuition is determined by natural laws, but faith is not. Intuition chooses the most probable among available situations and, at the same time, the most important for everyday life, but faith is the creative act of the person who transcends available experience.

Extending S. Bulgakov's thought (Bulgakov 1994:88-93), each religious thinker can be claimed to take one of three positions:

1. apophatism, which acknowledges the principal transcendence and unknowableness (unintelligibleness) of God

2. cataphatism, which states God is immanent to the world and to human consciousness

3. antinomism, which expresses the idea that 'the transcendent being is in the immanent one'.

The theorising of a religious thinker, indifferent to any position, must be based on the religious faith.

If faith is absent, the first position transforms into scepticism and then into atheism. The second position transforms into pantheism, dissolving God in everyday reality or into 'positive science', which does not need a 'hypothesis of God'. The third position looks for antinomy solutions through constructing complicated deductions, inserting various admissions that come to deteriorate in the grandiosity of theological conceptions, to 'death by a thousand qualifications' (A. Flew). Faith allows us to keep the tension of antinomies because it is a bridge between the transcendent and the immanent, and the bridge cannot be constructed by reason.

P.A. Florensky called various attempts by reason to test data on faith, especially believers' evidence of the supernatural being, 'demonic arrogance'. Florensky (1990) called faith in evidence, which can be tested by reason, 'an intellectual belief' and wrote:

There are many kinds of godlessness, but the worst of these is called 'intellectual belief', more exactly -'rational belief'. It is the worst kind, since it does not acknowledge a subject of faith ('the things invisible'), moreover it is hypocrisy: it acknowledges God to reject His self being - the invisible being, i.e., the super-rational being. (p. 64)

P. Florensky's consideration obliges us to conclude that if rational belief is demonic arrogance, then philosophy of

11.But then the whole of Frank's work 'Unfathomable' is devoted to grounding and explication of this thought. 
religion on the whole, because it states this belief, is demonic arrogance too, and Christians must not engage in philosophy. According to Florensky, this consideration is true. However, his pathos is directed against 'arrogance of reason', that is, against the pretension of reason to comprehend what exceeds human abilities. It is not directed against understanding religion, features of the world outlook based on relations between human and God, or understanding of these relations and comprehending this understanding, that is, against solution of the main problems of philosophy of religion. In the book The Pillar and Foundation of the Truth, Florensky states 'the most honest way' of theoretical representation of relationships between God and people lies through antinomies (Florensky 1990:162-164). At the same time, he asserts antinomies take place in human consciousness, in reason, but do not take place in the Divine sphere, and they are overcome through religious faith in the act of Communion. Antinomies are constitutive elements of religion, if it is thought rationally, but in the case where an individual appeals to God, he transcends his considerations, his available existence and himself. This case is an act of religious experience.

However, religious experience cannot be a criterion for verification of a faith because religious experience can turn out experience with false content. Ivan Ilyin wrote about this issue in the book Axioms of Religious Experience (Ilyin 2006:31). He distinguished three points of religious experience: subject (more exactly, the Subject), content and act. The Subject is the Perfection, the Idea, or the Most Real, that is, the reality that attracts everybody to itself through its perfection. The content of religious experience is what the individual or people believe in and what they confess as perfection and truth. It is not equal to the Subject of experience because content can be fantastic and objectless. Something can be experienced as illusory as perfection. An act of religious experience is how an individual or people believe, that is, a set of various psychical functions: emotions, affects, perceptions, imagination, thinking, will and others. I. Ilyin noted that a believer is able to accept the content of his religious experience for the subject of it when content is hypostasised, like if it was a perfect subject (Ilyin 2006:129-138).

Thus, faith leads an individual to religious experience, but experience can be illusory and false. Therefore, it must be examined by reason, which has to address the common experience of religious tradition to find correspondence with the religious experience of the individual.

\section{Conclusion}

Religious thought, as a thought about the relationship between people and supernatural beings, includes unintelligible and ineffable components that are accepted by faith. However, the majority of the components form the basis for various doctrinal statements, constructing a framework for theories both theological and philosophical. That issue is why Christian theological thought must maintain a balance between faith and reason.
Christian mystical discourse, at first sight, denies the significance of reason because mysticism is based on immediate revelation of God. However, conceptualisation of mystical experience requires rationalisation and the activity of reason to incorporate evidence of revelation in the system of ideas that exists in the religious tradition. Mystical thought has to proceed from vivid symbols and metaphors to propositions and deductions; it either finds correlates in theological tradition or creates a new theory used by various theological and philosophical concepts along with evidence of everyday experience that is known and convenient for its author.

Christian philosophical discourse is able to maintain unity of faith and reason, expressing it with antinomies, but often does not keep it in attempts to accomplish non-contradictory knowledge of the whole world that exceeds Christian dogmas. Sergey Bulgakov (1993) in the book Tragedy of Philosophy called these attempts 'philosophical heresies'. He wrote:

Logical monism, being natural necessity of reason - ratio - and implicating possibility of adequate, non-contradictory cognition of the world, is an ineradicable feature of any philosophical system, which pretends dimly or clearly, instinctively or consciously, timidly or militantly to be the absolute philosophy and looks at its sketch of being the system of the world. (pp. 312-313)

The history of European Christian theoretical thought demonstrates that faith provides for balance of contradictory propositions, which reason produces on the subject of faith. Rationalisation of the subject of faith and a search for proof warranting this subject have limits that are created by faith. At the same time, negation of the participation of reason in accepting religious subjects leads to mysticism, which can exist in the frames of the religious tradition only by its justification, including logical constructions foreign to mystical contemplations and illuminations.

\section{Summary}

In the entire history of Christian theoretical thought, unity of faith and reason was the dialectical contradiction, violation of which led to the destruction of religious discourse. Rational and irrational elements construct a contradiction in theology (which is a sort of religious discourse) because they logically deny each other, but they coexist in dynamic unity, which, in philosophy, can be expressed as an antinomy. If this dynamic unity is broken, theological discourse is transformed into mystical discourse (where irrational elements dominate) or into discourse of religious philosophy (where rational elements dominate). These discourses sit in proximity to theological discourse, but are not equal to it. The contradictory unity of faith and reason was researched in European medieval philosophy and Russian religious philosophy in the first half of the 20th century in theoretical systems that can be considered ways of explaining the relationship between faith and reason in Christian thought. Medieval authors attempted to find the most effective relationship 
between faith and reason for Christian theology. Russian philosophers attempted to transmit theological knowledge by means of philosophy in the secular age. Both of the methods demonstrate the dynamic unity of faith and reason as well as violation of it.

\section{Acknowledgement Competing interest}

The author declares that no competing interest exists.

\section{Author contributions}

I declare that I am the sole author of this research article.

\section{Ethical consideration}

This article followed all ethical standards for carrying out research without direct contact with human or animal subjects.

\section{Funding}

This research received no specific grant from any funding agency in the public, commercial, or not-for-profit sectors.

\section{Data availability statement}

Data sharing is not applicable to this article as no new data were created or analysed in this study.

\section{Disclaimer}

The views and opinions expressed in this article are those of the authors and do not necessarily reflect the official policy or position of any affiliated agency of the authors.

\section{References}

Alston, W.P., 1998, 'Religion, history of philosophy', in E. Craig (ed.), Routledge Encyclopedia of Philosophy (in 10 volumes), vol. 8, pp. 238-248, Routledge, London. Arnobius, Seven books against the heathen, viewed 12 March 2019, from http://www. intratext.com/IXT/ENG1008/_P2.HTM.
Augustine, All works - The Latin edition, viewed 12 March 2019, from http://www. augustinus.it/latino/ordine/index.htm. (In Latin)

Bratus, B.S. \& Inina, N.V., 2011, 'Faith as a general phenomenon of human consciousness', Moscow University Psychology Bulletin, Series 14: Psychology 1 , 25-38.

Bulgakov, S.N., 1993, Works in 2 vol., Nauka, Moscow. (In Russian)

Bulgakov, S.N., 1994, Unfading light: Contemplations and speculations, Respublika, Moscow. (In Russian)

Cherenkov, M.N., 2011, Protestant theology and philosophy of religion: meetings on borders of other, viewed 12 March 2019, from http://www.gazetaprotestant. ru/2011/09/protestantskaya-teologiya-i-filosofiya-religii-vstrechi-na-granicaxinogo/. (In Russian)

Davis, S.T., 2009, 'Revelation and inspiration', in T.P. Flint \& M.C. Rea (eds.), The Oxford handbook of philosophical theology, pp. 30-53, Oxford University Press, New York.

Dionysius the Areopagite, 1897, Works, viewed 12 March 2019, from http://ccel.org/ $\mathrm{ccel} /$ dionysius/works.pdf.

Florensky, P.A., 1990, Works in 2 vol., Pravda, Moscow. (In Russian)

Frank, S.L., 2000, Works, Kharvest, Minsk.

Frank, S.L., 2007, God with us, AST, Moscow. (In Russian)

Gregory Palamas, 2006, Triads for protection of sacred hermits, Kanon, Moscow. (In Russian)

Ilyin, I.A., 2006, Axioms of religious experience, AST, Moscow.

Jonathan, I.I., 2006, Enlightenment contested, Oxford University Press, New York.

Losev, A.F., 1991, 'The dialectics of myth', in A.F. Losev (ed.), Philosophy, mythology, culture, pp. 21-186, Politizdat, Moscow. (In Russian)

Migne, J.P., Complete course of patrology: Latin series, vol. 178, viewed 12 March 2019, from http://www.documentacatholicaomnia.eu.

Newland, T.C., 1974, 'D'Holbach, religion, and the "Encyclopédie"', Modern Language Review 3(69), 523-533. https://doi.org/10.2307/3724188

Plantinga, A., 1984, 'Advice to Christian philosophers', Faith and Philosophy 1, 253-271. https://doi.org/10.5840/faithphil19841317

Plantinga, A., 2000, Warranted Christian belief, Oxford University Press, New York.

Pojman, L. \& Rea, M., 2008, Philosophy of religion: An antology, Thomson Wadsworth, Belmont.

Smith, D.W., 1965, Helvetius: A study in persecution, Clarendon Press, Oxford.

Solovyov, V.S., 2011, Lectures on Godmanhood, Akademicheskiy proyekt, Moscow. (In Russian)

Swinburne, R., 2007, 'Philosophy of religion in the Anglo-American tradition', in V.K. Shokhin (ed.), Philosophy of religion: An almanac, pp. 89-136, Nauka, Moscow. (In Russian)

Taliaferro, C., 1998, Contemporary philosophy of religion, Blackwell, Cambridge.

Tatianus the Syrian, Address to the Greek, transl. J.E. Ryland, viewed 12 March 2019, from http://www.documentacatholicaomnia.eu/03d/0112-0185, Tatianus Syriacus,_Address_To_The_Greeks,_EN.doc.

Tertullian, Q.S.F., On the flesh of Christ, viewed 12 March 2019, from http://www. tertullian.org/anf/anf03/anf03-39.htm\#P9237_2537879.

Trubetskoy, E.N., 1998, Selected works, Feniks, Rostov-on-Don

Van Rossum, J., 2012, Palamism and sophiology, viewed 12 March 2019, from http:// kievrfo.org.ua/index.php/2011-12-21-23-44-19/2012-01-11-14-25-06/75-joostvan-rossum-palamism-and-sophiology-.

Vartanian, V., 1960, La Mettrie's 'L'Homme Machine': A study in the origins of an idea, Princeton University Press, Princeton. 